\title{
Development of a Prototype Pots and Potsherds Kilns for Facilitating Ceramic Wares Firing in Tertiary Institutions in Nigeria
}

\author{
Onofeagen John Ohimai ${ }^{1}$, Isah Bolaji Kashim ${ }^{2}$, Tolulope Lawrence Akinbogun ${ }^{2}$ \\ ${ }^{1}$ Department of Glass and Ceramics, Auchi Polytechnic, Auchi, Nigeria \\ ${ }^{2}$ Department of Industrial Design, The Federal University of Technology, Akure, Nigeria \\ Email: ohimaijoh@gmail.com, ibykash@gmail.com, akinbogun2003@yahoo.com \\ Received May $30^{\text {th }}$, 2013; revised June $30^{\text {th }}$, 2013; accepted July $7^{\text {th }}$, 2013
}

\begin{abstract}
Copyright (C) 2013 Onofeagen John Ohimai et al. This is an open access article distributed under the Creative Commons Attribution License, which permits unrestricted use, distribution, and reproduction in any medium, provided the original work is properly cited.
\end{abstract}

\begin{abstract}
The purpose of this research is to design and produce a gas and wood fired kilns with waste pots and potsherds that are as efficient as electricity and gas operated kilns which are built using conventional refractory bricks. Waste pots and potsherds were collected from two different pot producing communities, that is, Ojah in Akoko Edo and Imiegba in Etsako Central Local Government Ares of Edo State. To determine the suitability of the sample pots and potsherds collected for the construction of the kilns, the following tests were carried out: shrinkage, porosity and insulating tests. Two kilns were designed and constructed, a gas and wood fired kilns. The firing space and the outer wall of the gas kiln were designed to be circular with one burner port using only potsherd and mortar without using whole pots. The wood kiln was designed to have circular internal firing chamber, two fire boxes and a chimney. The kilns were subjected to series of gloss firing with wood and gas as sources of fuel and the maturing temperatures were recorded. The efficiency of the kilns constructed revealed that they were capable of firing to temperature above $1200^{\circ} \mathrm{C}$ that was originally planned for it to be attained coupled with uniform heat distribution experienced without any indication of cold spot. These kilns are capable of sustaining the deficiency arising from lack of imported kilns that could be used to accomplish finished ceramic productions as it is being currently encountered in Nigerian tertiary institutions and cottage level industries.
\end{abstract}

Keywords: Potsherds Kilns; Prototyping Ceramic Education; Sustainability

\section{Introduction}

Firing clays for hard, durable and improved aesthetics is an art that cuts across cultures and races. According to Akinbogun and Kashim (2006), no ceramic process is ever complete without subjecting them to heat treatment such that they become impermeable to liquid. Firing, therefore, is an indispensable factor in the practice of pottery and ceramics.

Electricity supply in Nigeria since the late 1980s has become highly inadequate, epileptic and unreliable for kiln firing. With the high cost of importation resulting from high foreign exchange rate, maintenance of electrical elements for kilns and its accessories as well as the running cost of alternative fuel therefore makes research into affordable ceramics kilns for tertiary institutions and practitioners in Nigerians inevitable.

Ceramic production has thrived significantly from the late 1970 s to 1980 s both at industrial and cottage levels. Unfortunately, the decline in the Nigeria economy from the late 1980s to date has forced most of the existing industries to close down as a result of unsteady power supply from electricity and exorbitant cost of diesel and kerosene used in supplying kiln burners.

Various efforts and researches have been carried out over a period of time to develop different types of kilns that would cut down on cost and make local production comparative to the imported ones. Agberia (1993) opines that this effort has not yielded much result that is worth celebrating. This position was also buttressed by Akinbogun (2004) while commending the efforts of the ceramist at embarking upon construction of kilns by themselves. He however noted the short coming in their kilns to be limitation in their efficiency level, with firing temperatures limited to earthen ware temperature. He added that some of the kilns contain only a single wall of insulating bricks with very short life span. These deficiencies put together that he concluded are enough to make firing of ceramic wares tedious and less rewarding.

As observed from a trip to Kenya during a conference by International Society of Ceramics Art Education (ISCAE) and tour of some ceramic cottage industries during the conference, it indicated a lot of viability and hope for production and sales of ceramic products. The kiln used in one of their cottage industries, Earthenworks Pottery Company Limited at Nyali Beach (behind Nakumatt) Mombasa, was made of potsherds and it worked adequately for them at accomplishing firing low temperature bisque wares. The excitement of the tourist at these large ceramics pieces made it expedient also for some ceramists in Nigeria to try the Kenyan experience and see how it goes. Since Nigerians are more interested in high temperature ceram- 
ics, this research was conceptualized on an attempt to use the same material to build a kiln of higher temperature capacity that can reach glaze point of between 1200 - 1300 degree centigrade, bearing in mind that there are plenty of waste pots and potsherds in local pottery making centres, such as Ojah, Imiegba in (Edo state, Nigeria) and many others which have become trash and constitute environmental nuisance. This potsherd's was however harnessed for construction of kilns which reduced the problems arising from ineffective and inefficient kilns and cost of production, thereby made the firing of ceramic work more rewarding especially at the Federal University of Technology, Akure where this prototype kiln was built. The potsherd kiln below in Plates $\mathbf{1}$ and $\mathbf{2}$ was the sample produced at Earthenworks Pottery Co., Ltd., Mombasa, and Wamumu Rehabilitation Centre, Kenya which was the source of inspiration for this research.

According to Ohimai (2011), a kiln constructed with potsherds and pots was described as a firing chamber or furnace composed of pots and jumble potsherds that were capable of resisting, accumulating, retaining and conserving heat input from the heat source. Other refractory materials such as kaolin,

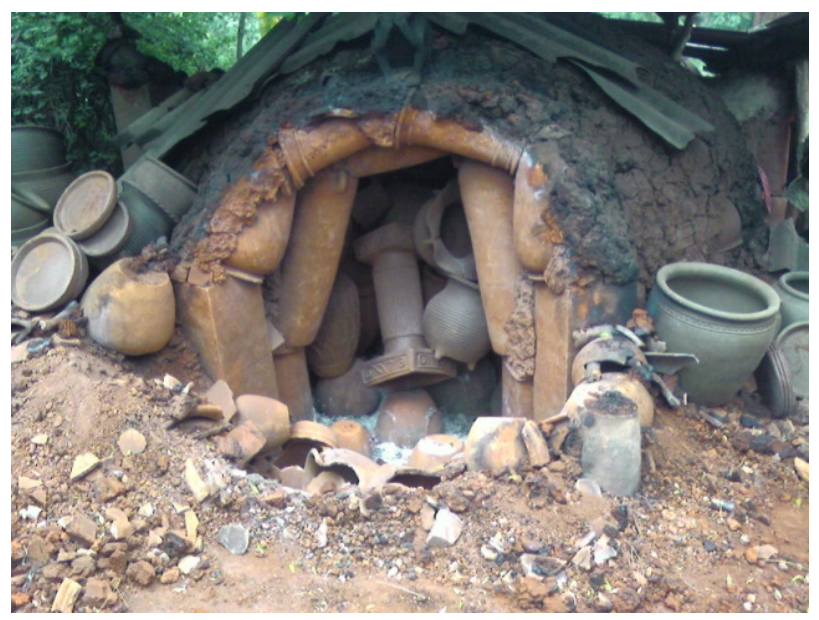

Plate 1.

A view of kiln from Earthenworks Pottery Co., Ltd., Mombasa, Kenya. Source: Ohimai, 2011.

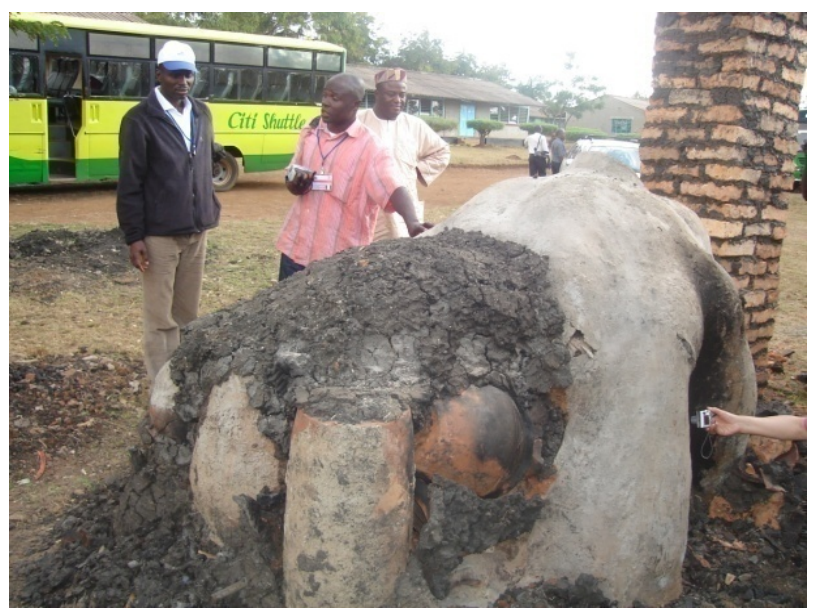

Plate 2.

Researchers examine the wreckage of kiln at Wamumu rehabilitation centre, Kenya after first firing. Source: Ohimai, 2011. ball clay and saw dust were sourced from Afowa in Edo State and Akure respectively in the construction process.

The aim of this project was to construct an efficient pot and potsherd kilns that can be used as an alternative to electric kilns with a view to cut down on overall cost of energy consumption required to accomplish ceramics firing in the tertiary institutions in Nigeria. The following objectives were accomplished in the course of this research:

- Collection of waste pots and potsherds for kiln construction

- Design a gas and wood kiln suitable for potsherd kiln construction

- Production of the kiln with good heat circulation up to stone ware and porcelain temperature

- Assess the insulating capacity of the earthenware pots and pot sherds when used as kiln wall and

- Determine the cost effectiveness of the kiln

\section{Methodologies Adopted for This Research}

In order to determine the suitability of the pots/potsherd samples collected for the kilns construction and the mortal fitness, as well as avoid excessive heat loss from kiln walls during firing, the following tests were carried out on the clays used for the pot and the mortar.

- Shrinkage tests

- Porosity or water absorption tests and

- Insulating tests.

Collection of waste pots and potsherd for kiln construction was sourced from local pottery centers in Edo state. The sorting of suitable pots and potsherds for the construction was done according to the research needs on arrival at the project site. The pots and potsherds sourced were of different sizes and shapes depending on their initial primary function. They pots and potsherds were from Ojah and Imiegba communities reputably known for the production of pottery in Akoko-Edo and Etsako Central Local Government of Edo State respectively as shown in Plates 3 and 4.

Objective 2: The designed high fired temperature kilns was operated on gas and wood as source of energy. To accomplish

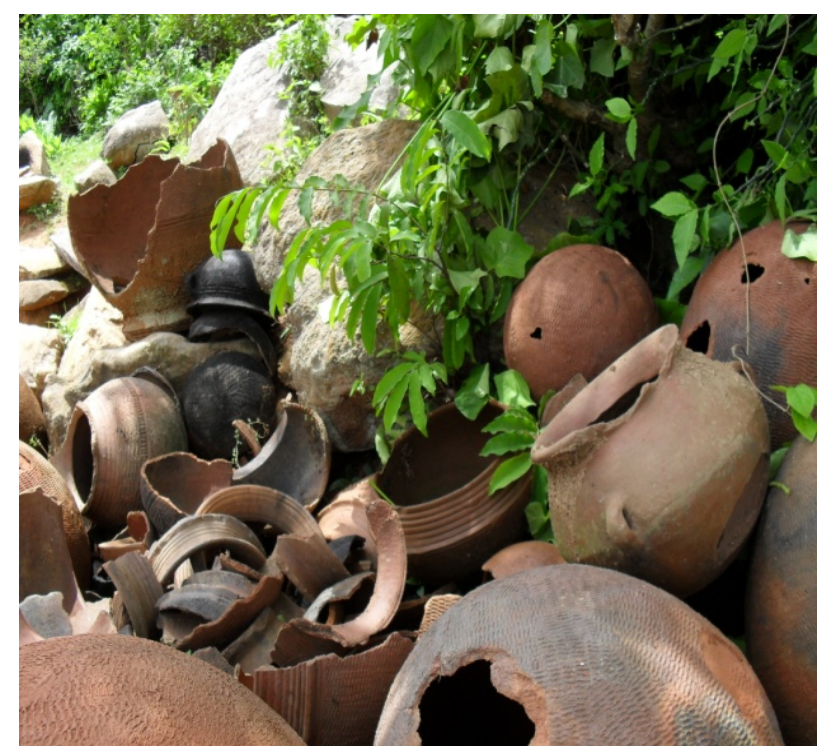

Plate 3.

Imiegba potsherds dump. Source: Ohimai, 2011. 


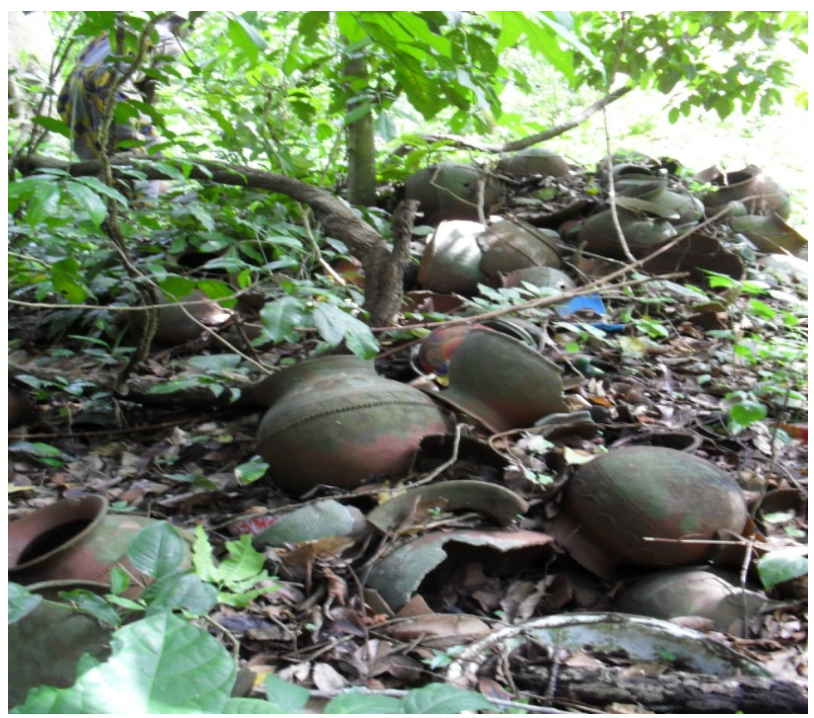

Plate 4.

Ojah Potsherds dump (over 100 years).

the construction of these kilns, an extensive literature search on kilns that uses gas and wood was carried out. For suitability, in terms of the internal space and kiln chamber, a round kiln was preferred because of its efficient heat circulation as recommended by Cardew (1971) who strongly posited that a round kiln has more even heat distribution advantages. Plates $\mathbf{5}$ to $\mathbf{2 0}$ indicate the pictorial process used in the construction of the kiln from its foundation to finishing as highlighted below.

The firing of both kilns shows that there was possibility of firing kilns constructed using pots and potsherds with gas and wood, coupled with very good and uniform heat distribution. Both kilns as observed by the researchers became more efficient with subsequent firing exercises. The kilns performance improved without either crumbling or forming glass phase. In all, four gloss firings were carried out; three gas firing and one wood firing. Plates 21 to 26 clearly show the stages at which the ceramic wares were loaded in the kiln, clamped and subsequently fired to finished gloss wares.

To assess the insulating capacity of earthenware pots and potsherds used as kiln walls, one was constructed with potsherds and the other with pots and potsherds. They were both subjected to series of gloss firing. The two kilns were not subjected to initial bisque firing before the gloss which is usually associated with firing in conventional kilns. To determine the amount of heat rise or retention inside the kiln and the external kiln temperature, several firings were carried out in the kiln and careful observation of the firing to porcelain temperature of $1353^{\circ} \mathrm{C}$ was done. It was difficult to conclude whether potsherd kiln will be as durable as kiln constructed with bricks, as the constructed kiln did not show any sign of depreciation. However firing with kiln constructed with potsherd was observed to be cost effective and fast firing. Since it is a popular adage that: "Time they say is money", the kiln did not only fire to $1200^{\circ} \mathrm{C}$ as desired but was fired to porcelain temperature of $1353^{\circ} \mathrm{C}$ at record time of three (3) hours without crumbling or forming glass phase. The firing procedure is pictorially explained from Plate 27.

The kiln proves very efficient at producing a very good gloss ware as shown in Plate 28 in the kiln constructed with

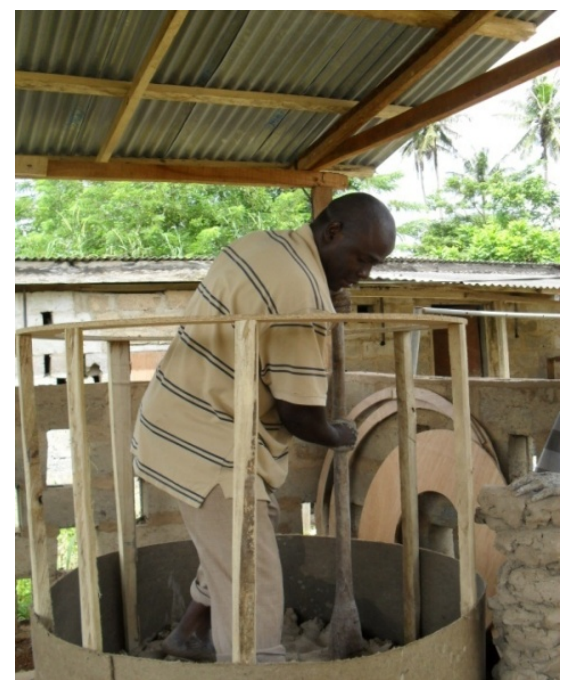

Plate 5.

Ramming mortar for kiln base.

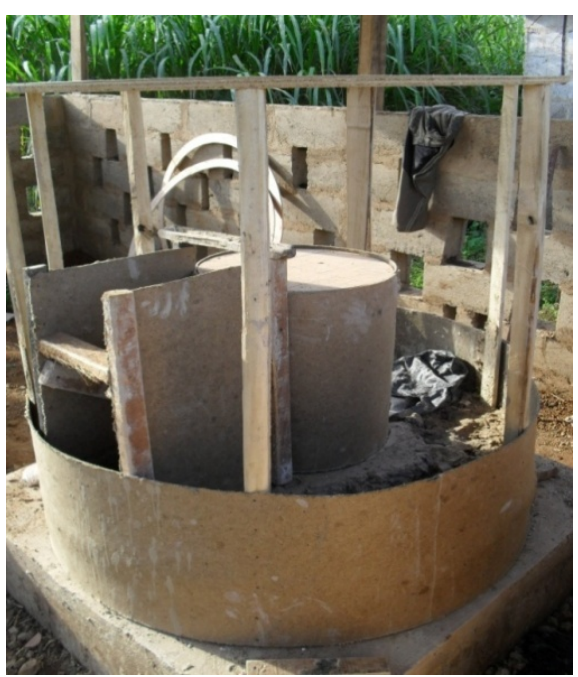

Plate 6.

Boarded kiln chamber and potsherd. Source: Ohimai, 2011.

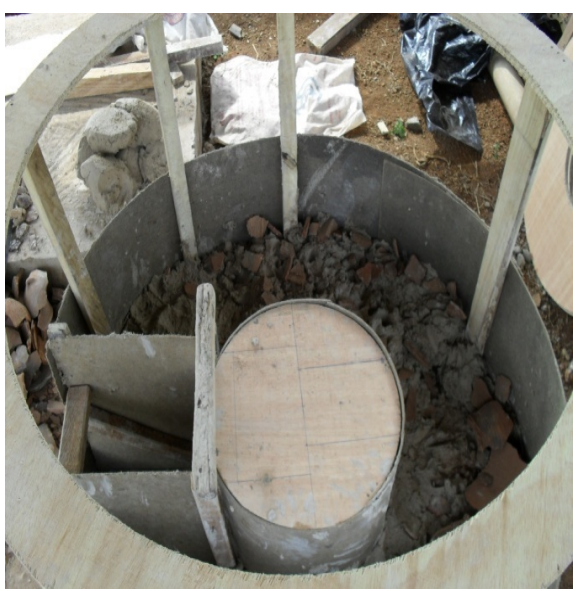

Plate 7.

Gas kiln war under construction. 


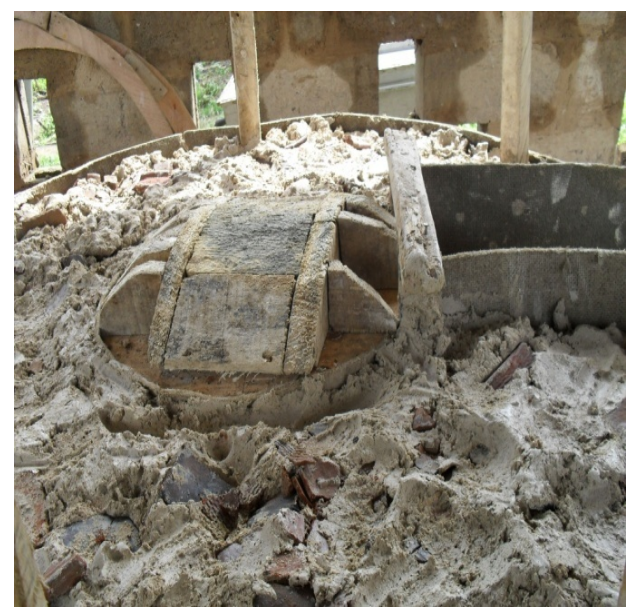

Plate 8.

Arch frame in position. Source: Ohimai, 2011.

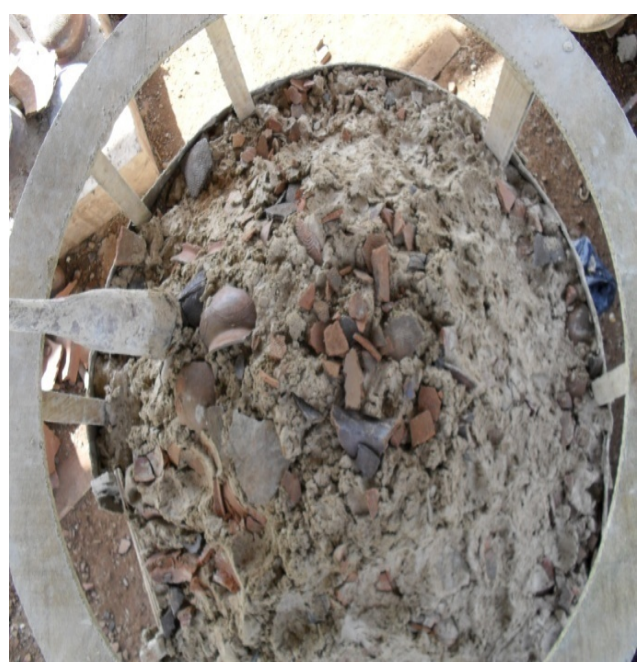

Plate 9.

Filling and ramming of kiln arch.

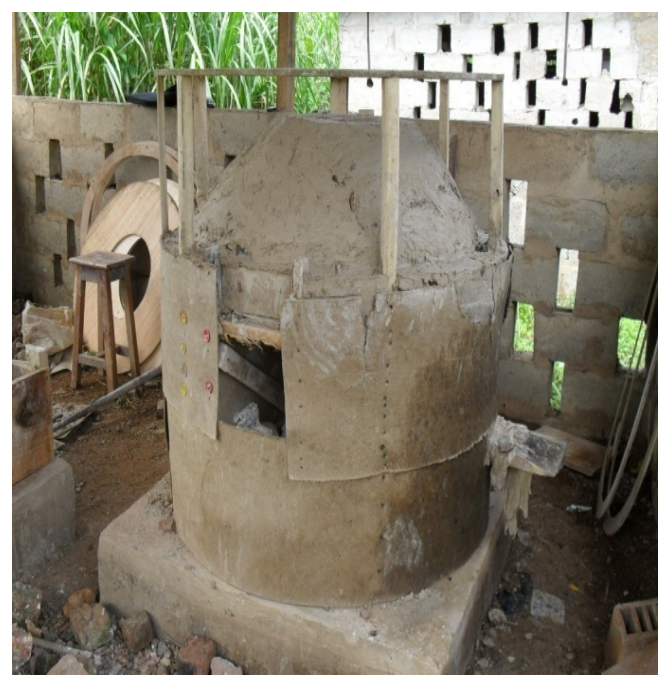

Plate 10.

Completed gas kiln without chimney. Source: Ohimai, 2011.

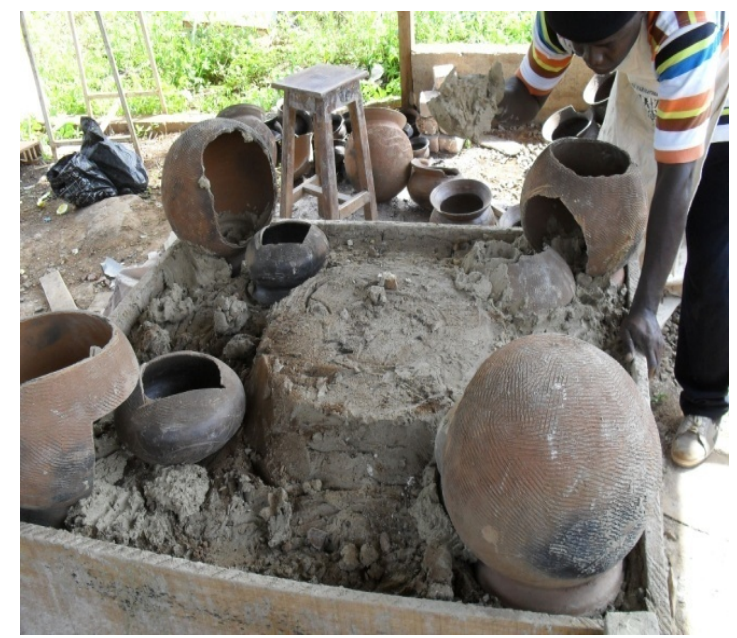

Plate 11.

Laying the first course of pots.

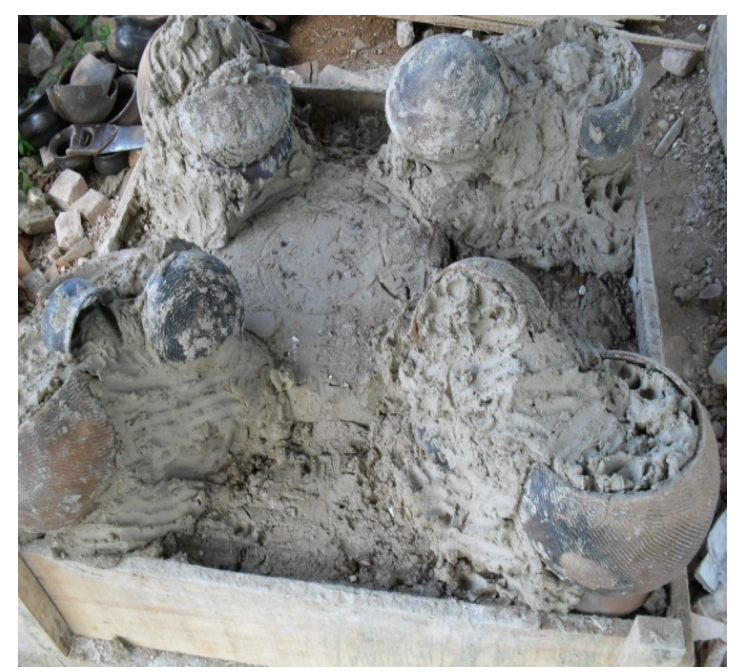

Plate 12.

Kiln pillars. Source: Ohimai, 2011.

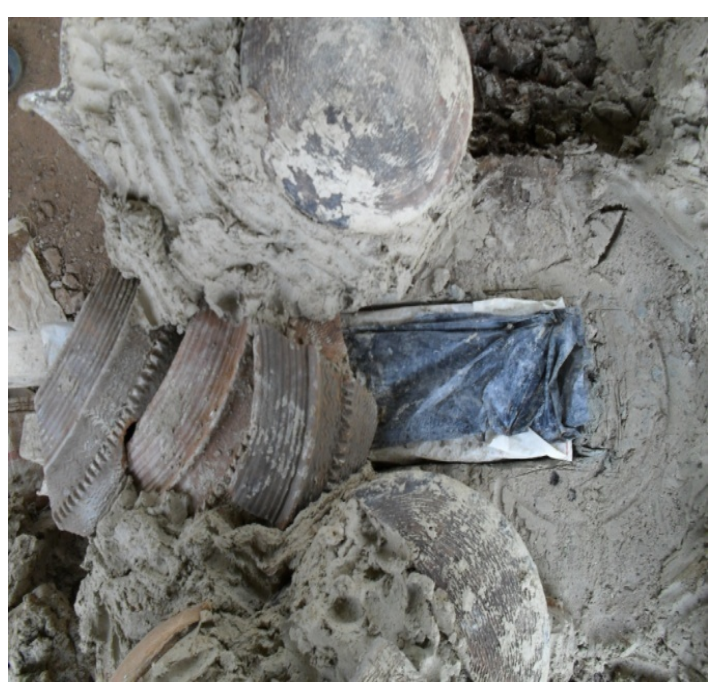

Plate 13.

Laying of kiln pillars continued. Source: Ohimai, 2011. 


\section{O. J. OHIMAI ET AL.}

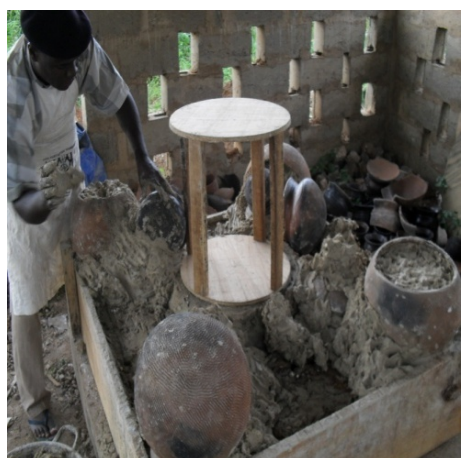

Plate 14.

A view of the expected flue leading to the chimney.

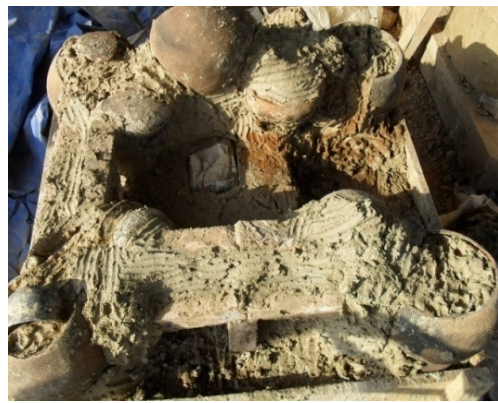

Plate 15.

Gradual building up of the wood kiln wall. Source: Ohimai, 2011.

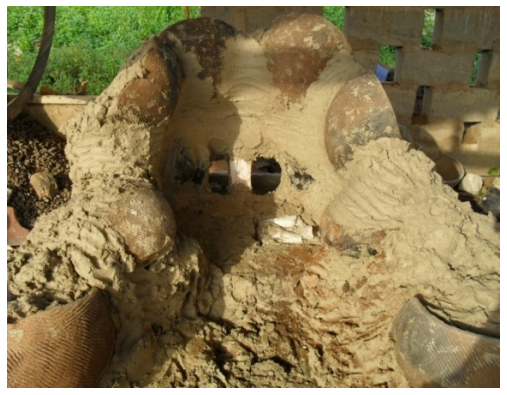

Plate 16.

Gradual building up of the wood kiln wall. Source: Ohimai, 2011.

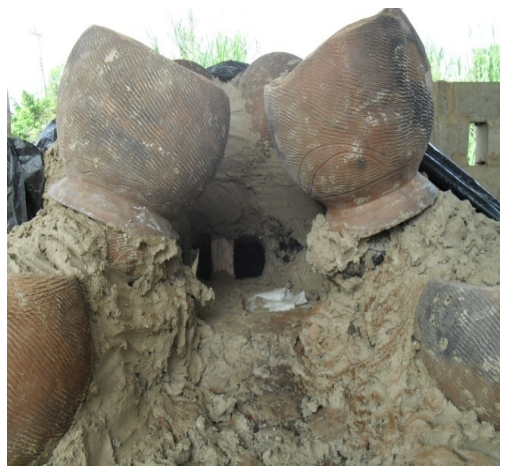

Plate 17.

Gradual closing up of the wood. Source:

Ohimai, 2011.

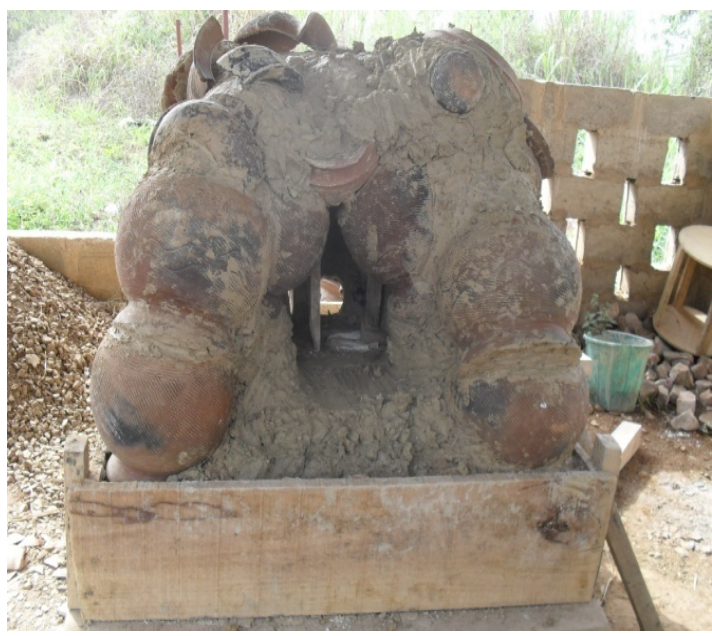

Plate 18.

Filling of wood kiln arch.

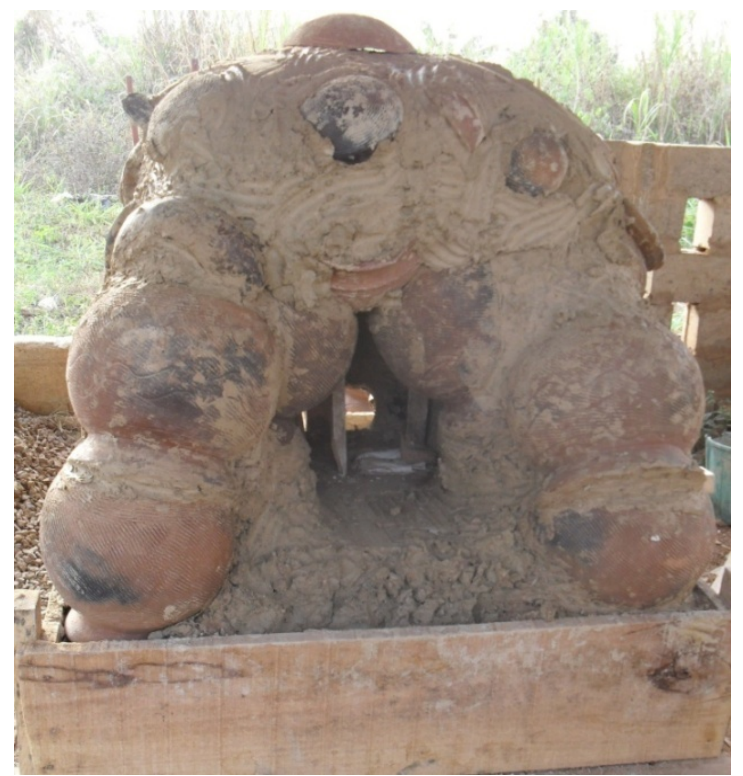

Plate 19.

Completed kiln without chimney. Source: Ohimai, 2011.

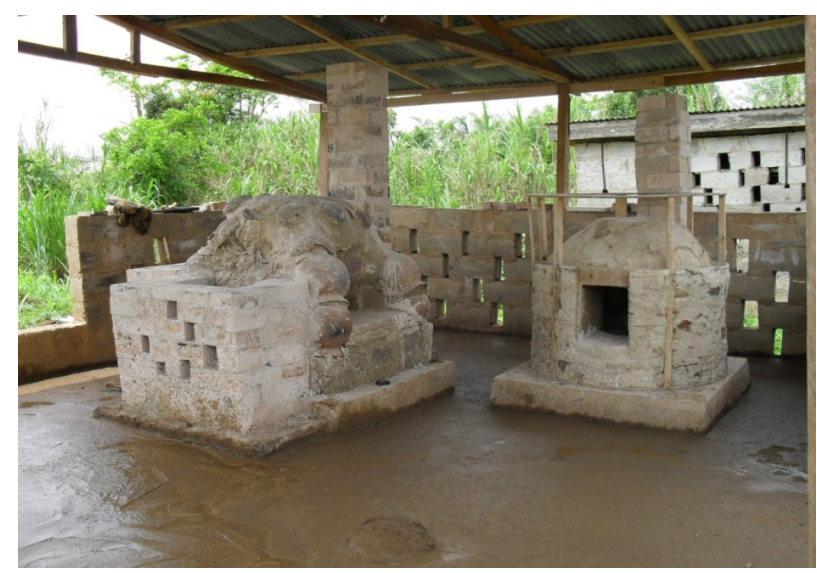

Plate 20.

Completed kilns with chimney. Source: Ohimai, 2011. 


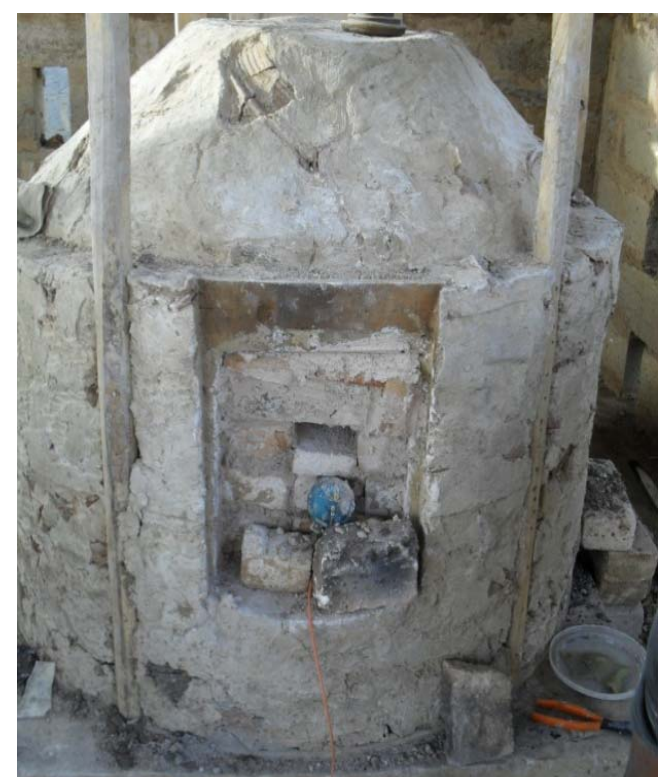

Plate 21.

Glaze works in kiln before firing. Source: Ohimai, 2011.

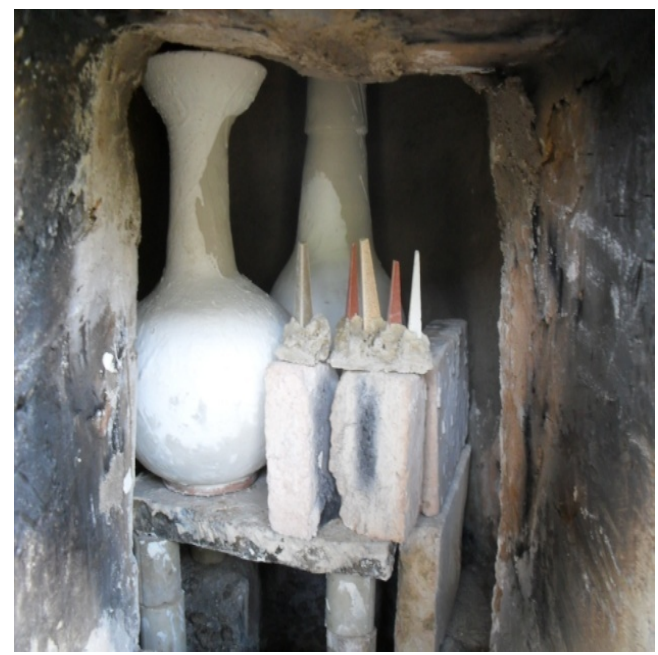

Plate 22.

Kiln ready for firing. Source: Ohimai, 2011.

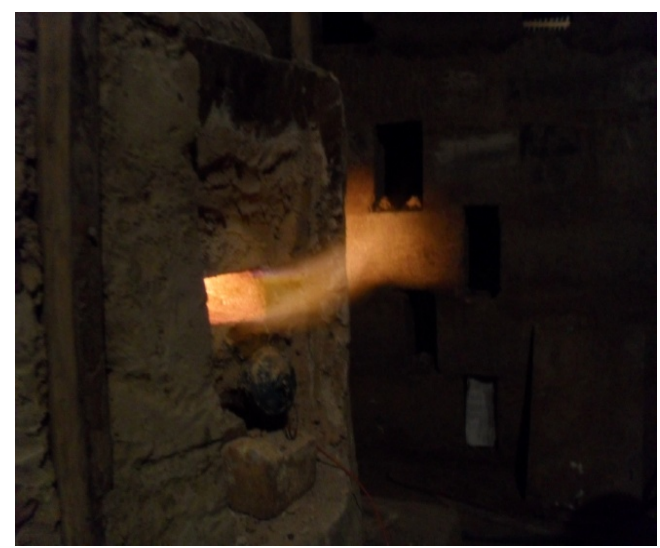

Plate 23.

Firing in progress.

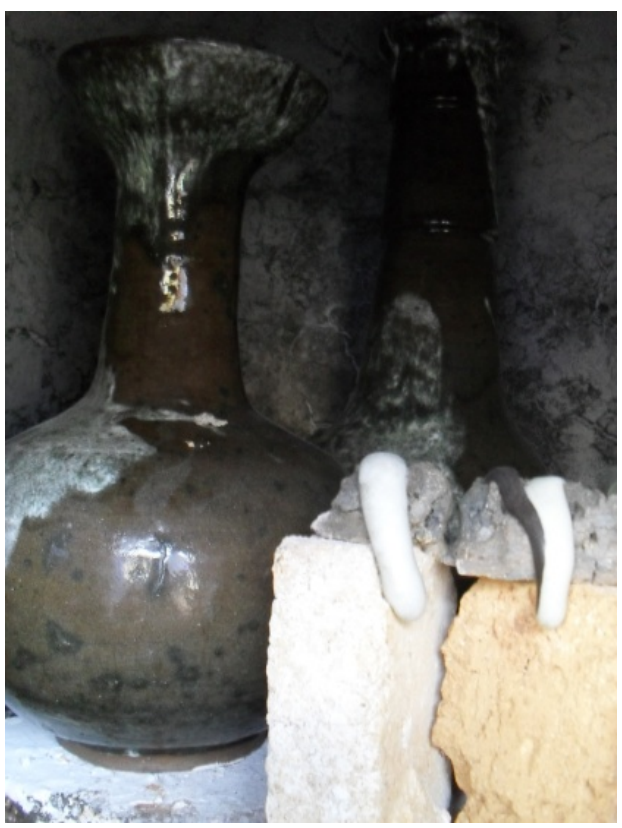

Plate 24.

Glazed work and melted Orton cones inside the kiln.

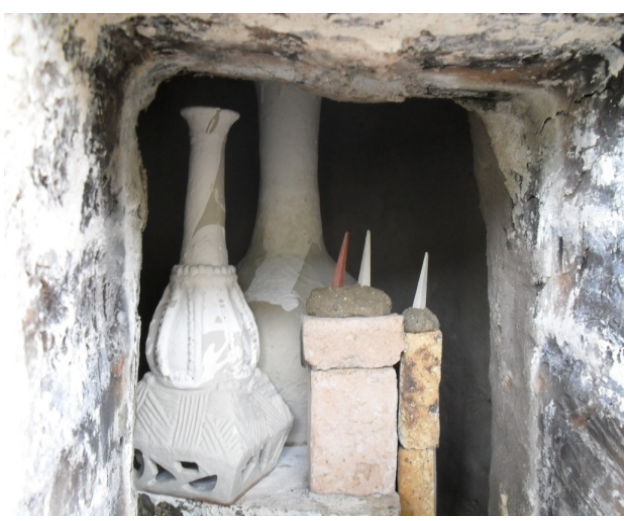

Plate 25.

Glazed wares before firing. Source: Ohimai, 2011.

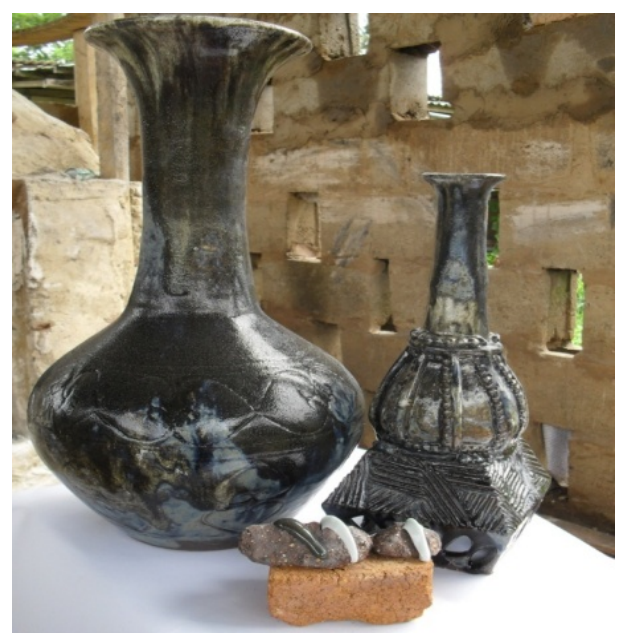

Plate 26.

Glazed ware from second firing. 


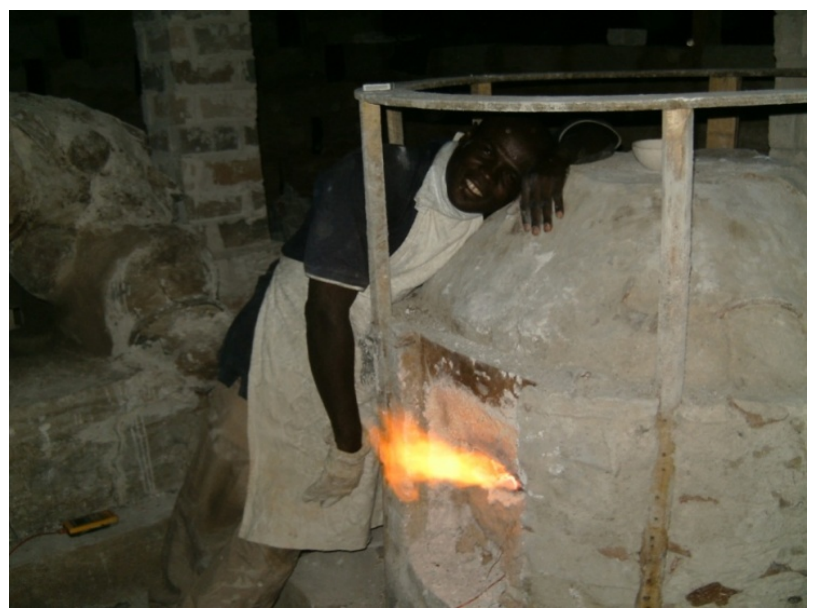

Plate 27.

At $1350^{\circ} \mathrm{C}$, the researcher observed by physical contact that the external walls of the kiln still felt cold.

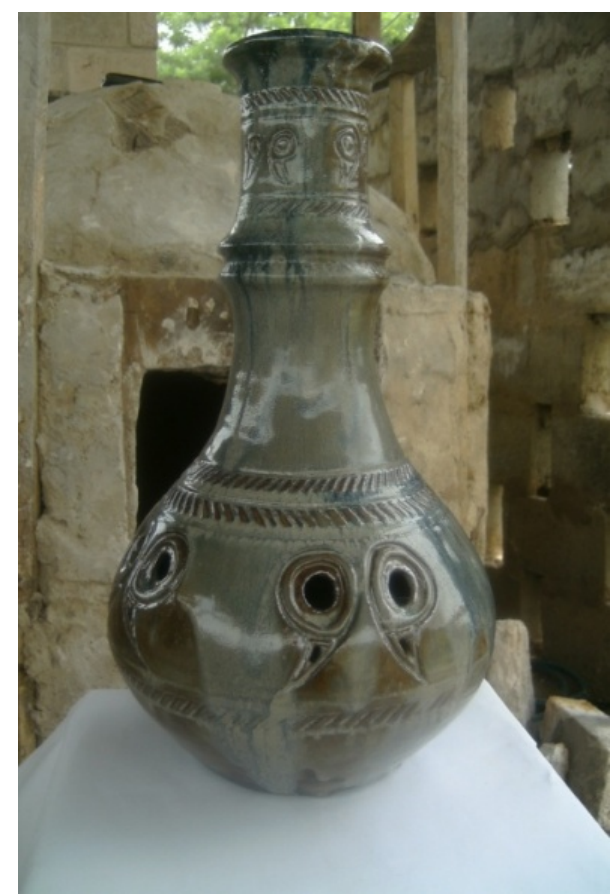

Plate 28.

Glazed wares from third firing. Source: Ohimai, 2011.

pot and potsherd.

Plates 29 and $\mathbf{3 0}$ show the measuring devices used to determine the kiln temperature, and Plates 31 to $\mathbf{3 2}$ show the wood stoking process while Plates $\mathbf{3 3}$ to $\mathbf{3 4}$ show the gloss ware inside the kiln after firing.

The cost effectiveness of kilns constructed with pots and potsherds using wood as a source of fuel for kiln firing was highly economical because wood can be found almost everywhere in the country, couple with large number of wood off-cut generated at various saw mills within the research study area. Though the use of wood might constitute hazards to the environment especially with the current campaign on global warming, but the current use of wood will go a long at resolving the production crises been experienced by institutions offering

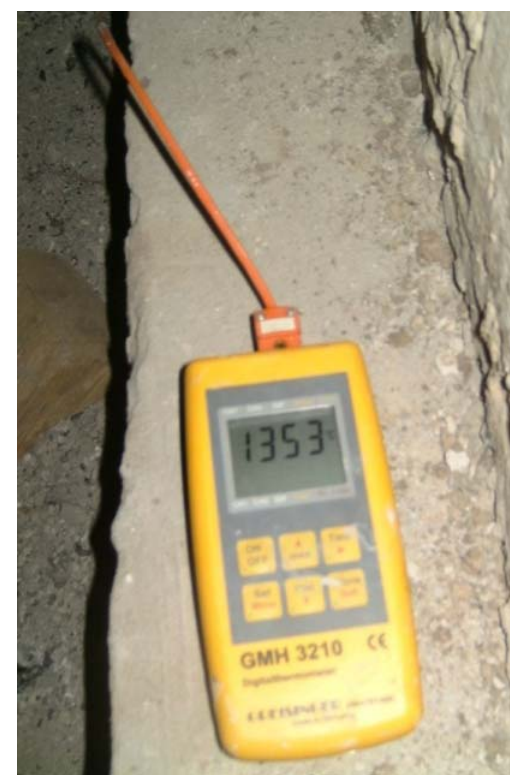

Plate 29.

Maximum temperature attained with the thermo couple with digital thermostat at end of third firing. Source: Ohimai, 2011.

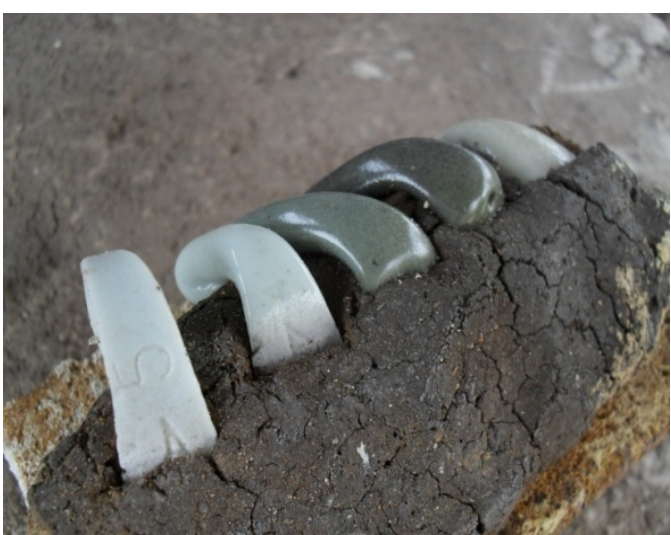

Plate 30.

Cones used for $4^{\text {th }}$ firing. Source: Ohimai, 2011.

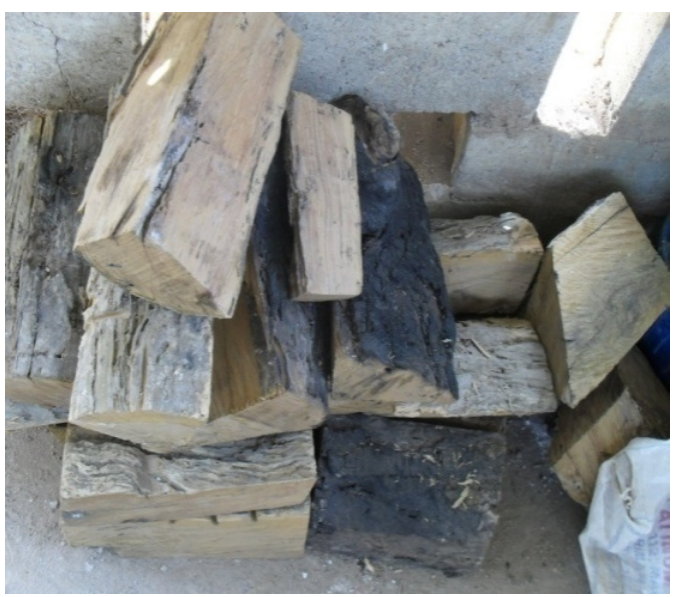

Plate 31.

Wood used for firing. 


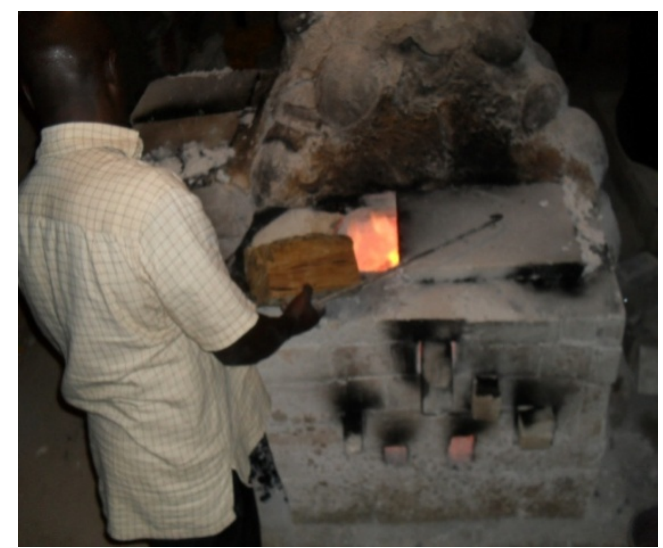

Plate 32.

Stocking during $4^{\text {th }}$ firing. Source: Ohimai, 2011.

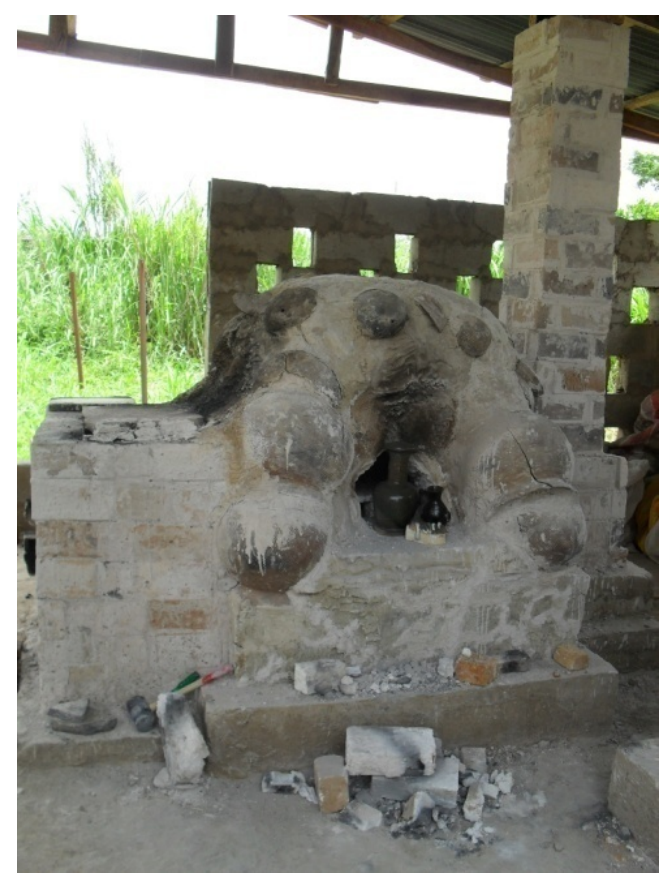

Plate 33.

Fired kiln and ware. Source: Ohimai, 2011.

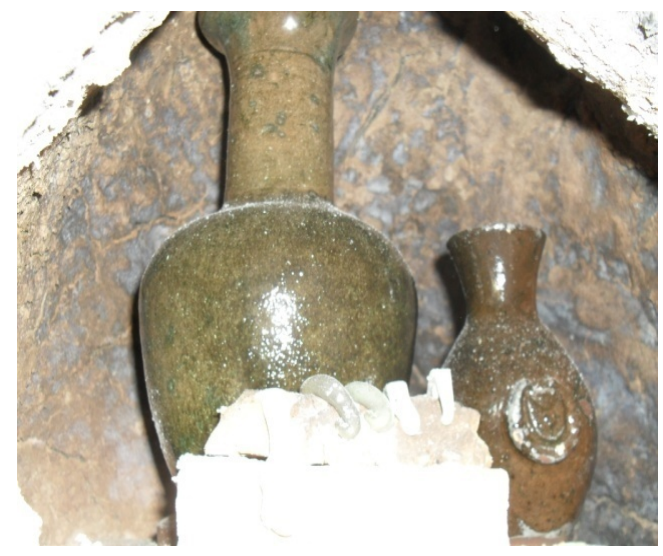

Plate 34.

Glazed wares from $4^{\text {th }}$ firing. ceramics in tertiary institutions in Nigeria. The wood for preheating the kiln were fell off from trees around the Department of Industrial Design Studio of the Federal University of Technology, Akure. The hardwood used is available as sawmill wastes in Akure, though it was observed by the researchers that they were still damp at the point of collection. This was eventually an advantage as supported by Rhodes (1981) that if the wood used for firing in kilns is slightly damp, the heat expended in volatilizing the water as steam lessens the amount of heat available for the kiln, while a properly designed kiln fired with dry wood of right size will advance in temperature very quickly. Hence the dried wood cut into sizes was sourced along the way from Auchi to Akure from peasant farmers. The gas used for the firing was sourced from Adebowale Gas Depot, Akure. Wood of less than one thousand (N1, 000) naira was used to fire the wood kiln to about $1230^{\circ} \mathrm{C}$. In the case of the gas kiln, $50 \mathrm{~kg}$ was bought with ten thousand, eight hundred (N10, 800) Naira only. Three gloss firing were carried out to $1221^{\circ} \mathrm{C}, 1236^{\circ} \mathrm{C}$ and porcelain temperature of $1353^{\circ} \mathrm{C}$ respectively with less than $25 \mathrm{~kg}$ of gas. The three gloss firing with gas cost an average of one thousand, eight hundred (N1, 800) Naira only per firing which was a good achievement in cost reduction over electricity and other mode of kilns used before this research effort.

\section{Findings}

There are plenty of waste pots and potsherds in local pottery making centres such as Ojah, Imiegba and many others which can be harnessed for the production of pots and potsherds kiln.

During the construction process, there were initial problems of cracks and incompatibility of mortar used to hold pots and potsherds together. Some of the pots also developed cracks due to shrinkage from the mortar used. However consistent mending and wedging of the cracks resulted in compacted walls that were stable after firing.

That kilns constructed with pots and potsherds can be subjected to straight gloss firing without consideration for the initial bisque firing usually associated with most conventional kilns, though the preheating hours of the first initial firing was longer.

The gas fired potsherds kiln as observed in the course of this research attained a porcelain temperature of $1353^{\circ} \mathrm{C}$ within three hours of firing without any defect such as crumbling or forming glass phase, a phenomenon that is very common with most locally constructed conventional kiln. This is because most locally built conventional kilns are limited in efficiency. The intended maximum firing temperature of some of the kilns when they are designed and constructed are hardly achieved due to inadequacies.

It was possible for heat in the kilns to rise to porcelain temperature of $1353^{\circ} \mathrm{C}$ without the outer walls surface getting hot. The simplicity and effectiveness of the kilns are based on some factors. It is a downdraft kiln made of new material innovation, inner circular wall allow for easy heat circulation coupled with thick walls usually associated with circular kilns without metal frame. The firing with kilns produced with pots and potsherds are cost effective and very efficient. Less than $25 \mathrm{~kg}$ of gas was estimated, at five thousand four hundred $(\$ 5,400)$ naira only at $1221^{\circ} \mathrm{C} ; 1336^{\circ} \mathrm{C}$ and $1353^{\circ} \mathrm{C}$, within the time duration of 3 hours, 3 hours 32 minutes and 3 hours respectively. While the wood of less than one thousand ( $\$ 1,000)$ Naira was used to 


\section{O. J. OHIMAI ET AL.}

fire the wood kiln to $1230^{\circ} \mathrm{C}$ within 8 hours.

It was discovered that while it is more economical to fire with wood, it is more efficient and less stressful to fire with gas.

\section{Recommendation}

A quasi experimental research on pot and potsherd kilns reveals that the kilns are highly effective and efficient in the firing of stoneware ceramics. They are also cost effective to operate for Institutional and cottage level pottery centres. Thus, for the design of pots and potsherds kiln, the principles stated below are recommended:

- That round kilns are better than rectangular kilns as recommended by Cardew (1971) and that principle rightly apply to these kilns during the series of firings carried out.

\section{Conclusion}

This study explored the possibilities of designing efficient ceramic kilns with the use of earthenware pots/potsherds. The assessment of the kiln at the end of the research reveals that pots and potsherds kilns are highly effective and efficient in the firing of high temperature ceramic products at very low cost. The study also reveals that the volume of potsherds and waste pots that end up in "pot cemeteries" are enough to stimulate pots and potsherds kiln production. This could liberate small scale ceramic industries, studio potters and students of ceramics in various tertiary institutions from the present decline that is rocking ceramic production outlets in Nigeria. It will encourage waste management as well as help in sustaining national development and sustainability of ceramics and ceramics production.

\section{REFERENCES}

Agberia, J. T. (1993). Design and construction of a gas fired kiln for ceramics production. Nigeria Journal of Technical Education, 10, 14.

Akinbogun, T. L. (2004). The state of small scale ceramics industry in South-Western Nigeria. Unpublished Ph.D. Dissertation, Akure: Federal University of Technology.

Akinbogun, T. L., \& Kashim, I. B. (2006). Issues in setting up cottage business. A focus on ondo and ekiti state. Ashakwu Journal of Ceramics, 3, 74-80.

Cardew, M. (1971). Pioneer pottery. London: Longman Group Ltd.

Ohimai. J. O. (2011). Development of efficient ceramic kilns using earthenware pots and potsherds. Unpublished Master Thesis, Akure: Federal University of Technology.

Rhodes, D. (1981). Kilns, design, construction and operation. Philadelphia: Cliton Book Company. 